\title{
The Theology and Classification of the Asomdwee Ntonton Nkabom Som
}

\begin{abstract}
This paper explores the theology and classificatory model of the Asomdwee Ntonton Nkabom Som. The classificatory model of New Religious Movements that this movement belongs to is unknown and not much has been written regarding its theology as well. Both primary and secondary sources were consulted. The complex and diverse nature as well as variety of taxonomies of New Religious Movements has partially contributed to the lack of consensus regarding having a precise definition. Based on existing classificatory model, this faith was classified as a Hebrais messianic movement. The movement has its unique and distinct theology, which to some extent, is similar to that of Christianity and Islam and this makes the movement to be seen outwardly as an amalgamation of Christianity and Islam. As such, a thorough research regarding the theology and cultural dimension of the faith is significant for Christian scholarship.
\end{abstract}

Keywords: Theology, Promised Messiah, RABBI, Adherents, New Religious Movements, Fantes

\section{INTRODUCTION \\ Definitions of Concepts}

It is important from the onset of this paper to clarify some key concepts associated with the vocabulary regarding the theology of the Asomdwee Ntonton Nkabom Som. Scholars such as John, Macquarrie, and Alister, E. McGrath have defined theology from different perspectives. ${ }^{2}$ In this study, theology is seen as a discourse about RABBI, which is seen in relation to the beliefs and practices of His given faith. Regarding the word Messiah, quite a number of scholarly works have also been done particularly regarding its definition from varying perspectives. ${ }^{3}$ For instance, a Messiah as a belief in a person who doubles as a religious and economic-political saviour meant to overthrow the existing world order and create a new one in its place. ${ }^{4}$ Nevertheless, in this study, a Messiah refers to a person anointed and sent by RABBI to deliver His people from all forms of satanic bondage as well as lead the adherents to the right way of worshipping Him. ${ }^{5}$ Similarly, numerous scholars in the field of New Religious Movements have dealt with the concept of Messianic movements in varying perspectives. ${ }^{6}$ In this regard, a Messianic movement in this write-up refers to a movement that revolves around an individual who is believed, mostly by the followers, to have certain powers beyond

\footnotetext{
John, Macquarrie, Principles of Christian Theology. (London: SCM Press, 1966) 1-4. See also Alister E. McGrath, Christian Theology: An introduction (Second Ed.). Oxford: Blackwell Publishers Ltd, 1997) 141-142.

Glenn W. Giles, Messianic movements of the first century. (Trinity Theological Seminary.

(Indiana: Trinity Theological Seminary, 2002), 4. See also Lucass Shirley (2011). The Concept of the Messiah in the Scriptures of Judaism and Christianity. Accessed July 13, 2019,

http://onlinelibrary.wiley.com/doi/abs/10.1111/j.1748-0922.2012.01601_22.x. See also Price Randall, The concept of the Messiah in the Old Testament - World of the Bible ..._Accessed July 18, 2019, http://worldofthebible.com/wp-content/uploads/2017/03/The-Concept-of-the-Messiah-in pdf on 12.

Shirley, The concept of the Messiah.

Adam Iddrissu Shaibu, Nyame Somafo Yaw: His calling, mission and Messiahship. (Oguaa Journal of Religion and Human Values. Vol. 5: Issue 1: (2019): 3

James, W. J. Fernandez, African Religious Movements-Types and Dynamics. Journal of

Modern African Studies, Vol. 2, No. 4 (Dec. 1964): 534. Accessed April 5, 2019, https//www.jstor.org/stable/159275.
} 
the prophetic and in turn, identifies himself with Jesus Christ because of the powers. ${ }^{7}$

Finally yet importantly is New Religious Movements (hereinafter referred to as NRMs), which has also been defined from different standpoints by scholars in the field. NRMs, which is a worldwide phenomenon is complex and diverse in nature. Mostly, the definitions given by scholars of New Religious Movements are partially influenced by their academic orientation. For instance, Eileen V. Barker sees the New Religious Movements to cover a disparate collection of organisations, most of which have emerged in their present form since the 1950s, and most of which offer answers to questions of a fundamental, religious, spiritual or philosophical nature. ${ }^{8}$ To this end, NRMs play significant roles in the lives of their adherents, which in some cases have transformed the lives of the latter. It is significant to note that if the letter ' $\mathrm{N}$ ' in NRMs refers to 'New', which partially implies that NRMs provide new interpretations to Scripture or new ways of practicing a religious faith, which is partially or totally distinct from an existing one, then some religious movements that existed during the first century could be classified as NRMs at that time. In this regard, one can consider Christianity, for instance, as NRM of the first century seeing it has its root from Judaism. ${ }^{9}$ As Barker rightly observes, NRMs cover a disparate collection of organisations; yet, the phenomenon of NRMs predated the 1950s.

Nonetheless, Gordon, J. Melton posits that NRMs are primarily defined, not by any characteristics that they share, but by the tension in their relationships with other forms of religious life represented by the dominant churches. ${ }^{10}$ According to him, NRMs are religious groups that are found, from the perspective of the dominant religious community, to be unacceptably different. According to David, G. Bromley, NRMs are groups that manifest a low level of alignment with dominant cultural patterns and social institutions of their society at a given historical moment such as the present. ${ }^{11}$ In contrast, dominant religious groups entail groups that are most strongly aligned with dominant cultural patterns and social institutions, typically, falling under the umbrella of mainstream churches. Bromley's formulation, like Melton's, entails a relational conception of NRMs defined not in terms of any internal property or in terms of chronological newness, but in terms of a group's relation to dominant institutions and symbolic patterns. Nevertheless, NRMs in this paper is seen as an indigenous African form of expression and manifestation of religiousity and spirituality resulting from the interaction between the traditional religions and worldviews on the one hand and the non-African religious traditions on the other.

In spite of their proliferation and the daunting challenges associated with reaching a consensus regarding its definition, NRMs are complex and diverse in nature. These complexities and diversities are also reflected in their classifications by scholars. This is partially because NRMs vary significantly doctrinally, liturgically and structurally. It is against this backdrop that this study seeks to bring to light, the theology and the category of classification that the Asomdwee Ntonton Nkabom Som belongs to within the family of NRMs in Africa. The rationale is that, since its inception few years ago, there is no literature covering the theology and the category of NRMs that this faith belongs to. This is done using interviews and participant observation. Additionally, published and unpublished book as well as the 2018 calendar of the Asomdwee Ntonton Nkabom Som were consulted. The next section of this paper deals with the phenomena of NRMs and this is followed by the classification of the Asomdwee Ntonton Nkabom Som. Thereafter, the theology of the faith and conclusion are addressed.

\section{The Phenomenal nature of New Religious Movements}

As Ibrahim, Murtala rightly observed, from the middle of the twentieth century to date, the world has witnessed the phenomenal rise and presence of NRMs in an alarming proportion. ${ }^{12}$ In spite of their proliferation, there has been a daunting challenge that scholars and other stakeholders are faced with in reaching a consensus on the precise definition of the concept. John, A. Saliba, has addressed the difficulties associated with this. ${ }^{13}$ Saliba opined that NRMs are often characterised by a particular inclusive doctrine in terms of world society. This point towards something one could possibly call "world culture". NRMs offer innovative religious responses to the conditions of the modern world, despite the fact that most of them present themselves as rooted in ancient traditions. They are often highly eclectic, pluralistic and syncretistic. ${ }^{14}$

\footnotetext{
It is worth stating that the meaning of this movement differs from the religious understanding of a Messiah. In the religious context, a Messiah refers to a savior who will come in the near future to redeem his people.

Eileen V. Barker, New religious movements: A practical introduction. (London: HMSO, 1989) 25-26

9 Mary Jo Weaver, Introduction to Christianity. (California: Wadsworth Publ. Company, 1984), 43. See also, Bryan Wilson and Jamie Cresswell (editors), New religious movements: Challenges and response.(New York: Routledge, 1999),166.

10 Gordon J. Melton, “Toward a Definition of "New Religion”. Nova Religio: The Journal of Alternative and Emergent Religions. 8 (1), (2004): 73-87. Accessed April 5, 2019, https://doi.org/10.1525/nr.2004.8.1.73.

11 David, G. Bromley, Perspective: Whither New Religions Studies? Nova Religio: The Journal of Alternative and Emergent Religions, 8 (1) (2004):75. Accessed April 5, 2019, https://doi.org/10.1525/nr.2004.8.1.73.

12 Murtala, Ibrahim, “The Rise and Proliferation of New Religious Movements in Nigeria”. International Journal of Humanities and Social Science, Vol. 3 No. 15 (August 2013):182. Accessed January 21, 2020, http://www.ijhssnet.com/journals/Vol_3_No_15_August_2013/21.pdf.

13 John. A. Saliba, "Understanding New religious movements". Nova Religio: The Journal of Alternative and Emergent Religions, 8 (3), (1997):122. Accessed April 5, 2019. https//: doi.org/10.1525/nr.2005.8.3.122.
}

14 Ibid. 
There is no doubt that globalisation has created favourable conditions for the proliferation of NRMs throughout the world. Neither globalisation nor NRMs are really new phenomena, but in the middle of the twentieth century both assumed strong power and far reaching influence. The forces of globalisation have created a fertile ground for the growth of NRMs throughout the world. Additionally, social liberalism, which minimized conservatism, has given people more freedom to join the religion of their choice. Michael, T. Cooper posits that liberalism renders legitimacy to cultural pluralism, which gives rise to a multitude of worldviews in human society. ${ }^{15}$ Moreover, liberalism allows the fermentation of a new religious ideology or group to develop and proliferate in the new global world, without unbearable pressure to conform to conventional social norms. In Africa, like the rest of the world, there are so many of these NRMs in existence engaged in vigorous mission activities competing with the established classical religious institutions for membership. Nonetheless, some of these movements have short life spans and some have very insignificant membership. Besides, some have become very influential not only in Africa but in the world in general. In Ghana for instance, there are quite a number of these NRMs springing up as a result of interaction of the primal society and its religion with the more powerful and sophisticated cultures and their major religions, resulting in some substantial departure from the classical religious institutions.

Contributing to the debate, Harold W. Turner thinks the concept has frequently been used to describe a religious phenomenon of the $20^{\text {th }}$ century. ${ }^{16} \mathrm{He}$ describes Christian-related NRMs as "churches founded in Africa by Africans primarily for Africans and which lack the substantial association with Christianity found in almost all the older churches". Turner's comment does not mean that NRMs are only found in the African continent, but that it is a worldwide phenomenon. He considers these new movements as "Independent Churches".

NRMs in Africa can be seen in relation to NRMs in societies where the indigenous faith still exists. ${ }^{17}$ This designation was primarily aimed at distinguishing NRMs in non-Western societies from those in Western societies. The term also implies an encounter with primal or traditional religions and foreign religions as well as with other aspects of social change. The complex nature, origin, as well as the varied forms of NRMs has led African scholars to give various designations or classifications to NRMs, especially Christian related. ${ }^{18}$

It is a fact that NRM, like religion in general, does not lean itself to easy study or analysis given its complex nature and this makes its study as bewildering as it is fascinating. ${ }^{19}$ It is important to note that each term appears to describe a particular type or an aspect characteristic feature or circumstance of origin or emphasis on belief or practice of the NRM in question or in general. In this concern, the concept or any particular concept is unlikely or does not apply to all NRMs. Additionally, no single concept appears to or can indeed adequately describe the totality of such a complex phenomenon as NRMs. ${ }^{20}$ Whiles at the same time some concepts turn to overlap with others. Hence, all these point to the fact that NRMs could mean different things to different people. And any particular concept used to describe the phenomenon could be understood differently at different times and places.

\section{Classification of the Asomdwee Ntonton Nkabom Som}

NRMs have been variously classified by different scholars over the years and have additionally expanded in scope and complexity. It is worthy to note that the situation of diverse classifications is consistent with the nature of NRMs as a whole and the tendency for these movements to assume complex or complicated characteristics at any given point in time. The concept is embraced with bewildering variety of taxonomies coined by scholars such as David B. Barrett, Bryan R. Wilson and Turner. ${ }^{21}$

Over the years, different scholars have used similar and different indices and criteria of interpretation and analysis to construct classificatory models. In fact, the classifications of NRMs vary greatly doctrinally, liturgically and structurally. The items in the models could be understood or analysed differently by different scholars at different times and places or even at the same time and place. It is significant to add that the models keep changing and expanding and have become increasingly diversified, complex and indeed sometimes confusing. All these are quite consistent with the nature of the phenomenon of NRMs.

It is prudent to mention briefly some classificatory models given by NRMs scholars as well as briefly identify

15 Michael, T. Cooper, Druids Globalization and Constructing a Postmodern Religious Identity. Centre for the Study of New Religions. The 2007 International Conference (Bordeaux, France, 2007).

16 Harold W. Turner, History of an African independent Church. (Oxford: Clarendon Press, 1967).16

17 Turner, "The way forward in the religious studies of African primal religion". Journal of Religion in Africa, Vol. 12, Fasc. 1 (1981):2

18 Turner, "Religious movements in primal (or Tribal) societies". New Vista Missionary \& Ecumenical, Vol. 9 (3) (1981): 48. See also David, B. Barrett, Schism and renewal in Africa: An analysis of six thousand contemporary religious movements. (London: Oxford University Press, 1968 ) 48.

19 George D. Chryssides, "New religious movements-Some problems of definition". Accessed on January 12, 2020. http://jbasr.com/basr/diskus/diskus1-6/ CHRYSSI2_2.TXT

20 George D. Chryssides, "New religious movements-Some problems of definition”. Accessed on January 12, 2020. http://jbasr.com/basr/diskus/diskus1-6/ CHRYSSI2_2.TXT

21 David. B. Barrett, Schism and renewal in Africa: An analysis of six thousand contemporary religious movements. See also, Bryan, R. Wilson, Magic and the Millennium: A Sociological Study of Religious Movements of Protest among Tribal and Third World Peoples. (London: Harper and Row,1973)

Turner, “Africa." In The Study of Religion: Traditional and New Religion, edited by Stewart Sutherland and Peter B. Clarke, (London, 1991$)$ : 189. 
one of such classificatory models. Barrett has employed three models in his classification, which are, those that are Christian type, Independency and heterodox. ${ }^{22}$ The Christian type are religious movements that are Christocentric and are within the mission churches. Such movements are often referred to as revivals, renewals, or reform movements within the mission churches. An illustration is the Catholic Charismatic Renewal movement. The Independency are also Christocentric but are outside the mission churches. An example is the Army of the Cross of Christ Church (Popularly known as the Musama Disco Christo Church). The third classificatory model are movements that are either non-Christian or cannot properly be called Christian. An example is Zetaheal.

Adding his voice to the classificatory models, Turner writing on religious movements in primal societies coined four classifications namely, neo-primal, Independent, Synthesist and Hebrais. ${ }^{23}$ The Neo-primal movements, according to Turner, are NRMs that have the proclivity towards reviving the indigenous faith of the African. An illustration is the Afrikaner Mission of Ghana. The Independent Churches are Christian related movements that have contextualized Christianity to suit the African socio-cultural context. An example is the Army of the Cross of Christ Church (Popularly known in Ghana as the Musama Christo Disco Church). The Synthesist, nevertheless, are religious movements that combine selected elements of different religions and an illustration is the Zetaheal movement in Ghana. Lastly, the Hebrais are movements that have significant inclination towards Judaism and emphases the Old Testament often and above the New Testament. ${ }^{24}$ Additionally, the Hebrais movements have effected a complete transference from the indigenous faith into Biblical context. In addition, the Hebrais movement see themselves either as Israelites or descendants of ancient Israel, especially, the lost ten tribes. ${ }^{25} \mathrm{~A}$ worthy illustration of this classificatory model is the Seven-Day Church of Theocracy in Ghana.

It can be realised that from the above classificatory models, the Asomdwee Ntonton Nkabom Som can be placed either within Barrett's heterodox movements or within Tuner's Hebrais movements. Nevertheless, with a careful consideration of what entails in the two models, one realises that the Asomdwee Ntonton Movement perfectly fit in Turner's Hebrais movement.

Although, the Seven-Day Church of Theocracy and the Asomdwee Ntonton Nkabom Som correspond with Turner's Hebrais movements, a significant distinction exist between them particularly, regarding their core fundamental belief. For instance, whiles the Seven-Day Church of Theocracy is Christocentric, the other is anti-Christocentric. The latter recognises Jesus Christ as one of the messengers of God and not the expected Messiah prophecied in the Old Testament. ${ }^{26}$ According to the leader and founder of the latter movement, God had fulfilled His promises to Israel and Saudi Arabia by sending Moses and Prophet Mohammed (S.A.W.) with Judaism and Islam respectively. In this regard, Israel's expectation of a Jewish Messiah is a mirage since the expected Messiah is supposed to come to Ghana. ${ }^{27}$ In this regard, he is the expected Messiah that the Jews are expecting.

Inferring from the immediate paragraph, it is clear that Turner's Hebrais classificatory model can be group into two namely, the Christocentric and Anti-Christocentric Hebrais movements. The Asomdwee Ntonton Nkabom Som, which is within the Anti-Christocentric Hebrais movement is Messianic inclined since it exhibits certain characteristics typical of messianic movements that have been argued by Fernandez and Barrett. ${ }^{28}$

It is Messianic because Nyame Somafo Yaw, is seen and recognised as a special or God ordained person. According to the mother, the son during his childhood days to date has been a 'wonder child', one with special abilities. She claimed, for instance, that during his childhood days, he used the bare right palm to take fire from the coal pot for the father to light his cigar without any burnt on the palm. 'Such incidences continued when the father was alive and people who saw or heard of them were surprised' ${ }^{29}$ Additionally, the messianic taxonomy is appropriate because the founder and leader of the movement is seen and proclaimed by the followers as the promised Messiah sent by RABBI to Ghana and the world at large as illustrated in fig. 1 below. ${ }^{30}$ In fact, he and his adherents claim that he is the Messiah that Aryeh Kaplan thinks Jews believe will come. ${ }^{31}$

The leader and founder asserts that the dynamic nature of the world repeatedly makes some people forsake God for material things and end up becoming Satan's children. ${ }^{32}$ Satan then takes the opportunity to infiltrate or send agents to God's house and, consequently, the true religion of God becomes idolatrised. To salvage such a situation,

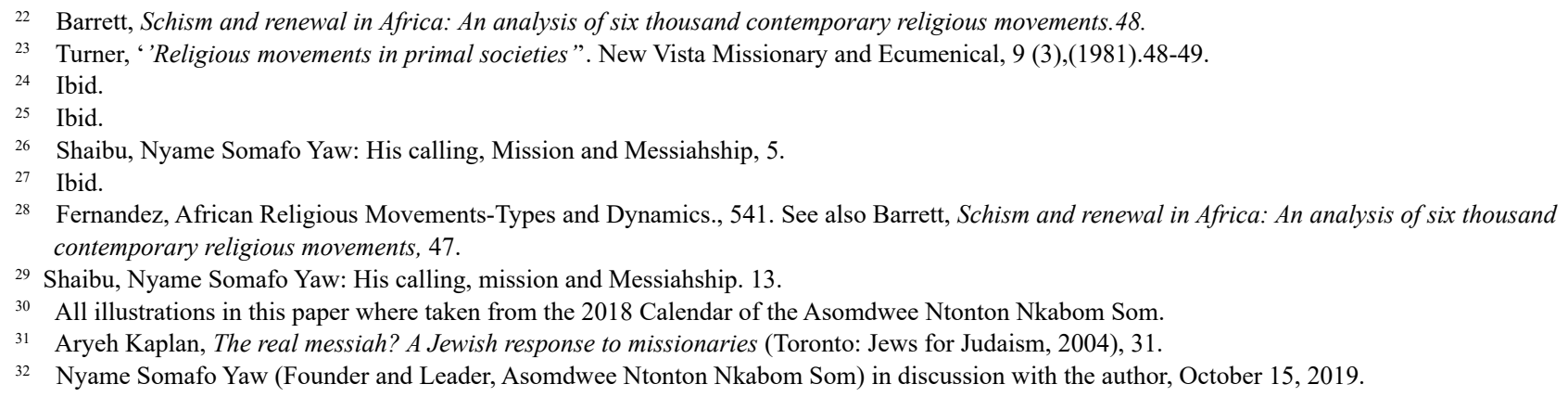


God occasionally sends a messenger to come and redirect his children to the right path. Before and after Noah's flood, God has sent several prophets and messengers to the earth to redirect humankind to His true worship. ${ }^{33}$ Similarly, in this twenty-first century, RABBI has sent Nyame Somafo Yaw to redirect Ghanaians and the world at large to HIS true worship. In other words, Nyame Somafo Yaw was commissioned by RABBI to deliver Ghana and the world at large from satanic bondage as well as redirect the world to the right path of worshipping RABBI. ${ }^{34}$

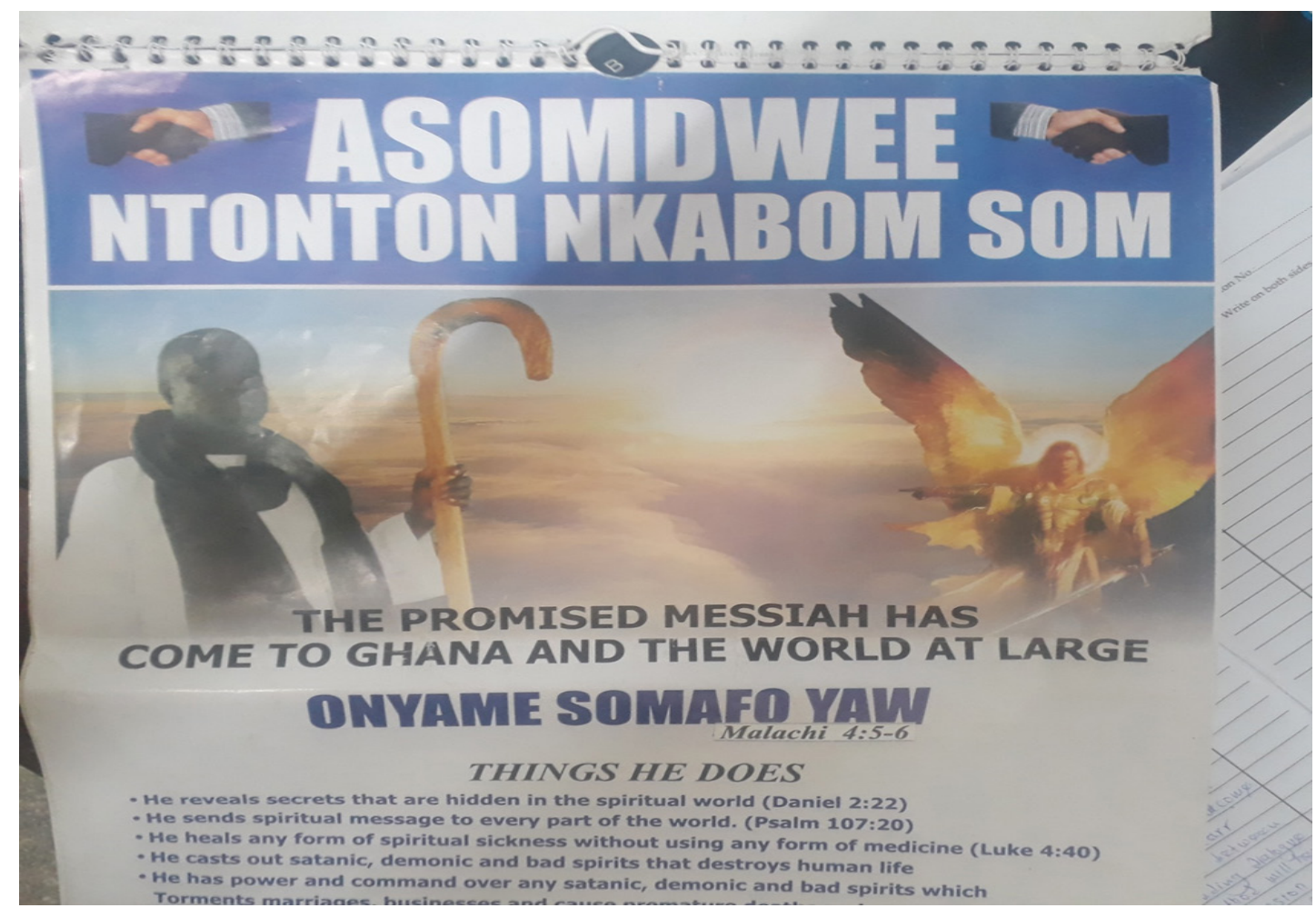

Fig. 1 A photograph of Onyame Somafo Yaw and issues empowered by RABBI to do and this was taken from the front page of the 2018 calendar of the movement.

In this regard, just as God gave Israel, Judaism through Moses and Islam for Saudi Arabia through Prophet Mohammed (SAW), God has given the Asomdwee Ntonton Nkabom Som to Ghana. This is in sharp contrast to Patrick E. Nmah who posit that NRMs in Africa have not provided new national religions. ${ }^{35}$ As a national religion, the Asomdwee Ntonton Nkabom Som, Nyame Somafo Yaw claims, will be firmly established in the nation by 2024 and by one hundred and fifty years of its existence, it would have spread all over the world. ${ }^{36}$

In addition, as part of his Messianic mission on earth, Nyame Somafo Yaw has been empowered by RABBI, to reveal secrets, send spiritual messages worldwide, heal all forms of spiritual sickness and exercise dominion over demonic and malicious spirits and this is captured on fig. 1 above. Regarding having dominion over satanic spirits, Nyame Somafo Yaw, in a sermon on $21^{\text {st }}$ of July, 2019, categorically stated that seventy per cent $(70 \%)$ of evil spirits residing in the sea and water bodies in Ghana have been rendered powerless and driven from their abodes by him. He further opined that the remaining thirty per cent would soon follow suit. This implies that very soon, Ghana would be free from the evil marine spirits.

In self-actualisation of another Messianic task, Nyame Somafo Yaw has built a temple, which stands at nine feet square under the instruction of RABBI. He claimed that his temple is the biggest since that of Saudi Arabia and that of King Solomon stood at seven feet square each. Additionally, his temple stands for forgiveness, healing, procreation and blessing. In addition, it is meant for progress and success in life and victory over one's enemies. ${ }^{37}$

As rightly observed by Fernandez, the faith rejects a good portion as well as blame the Ghanaian traditional religious practices for the nation's woes. ${ }^{38}$ The founder and leader, for instance, blames the great ancestors of the Akan ethnic group that went for the god AKOR in the course of their migration to the promised land for the genesis of

38 Fernandez, African Religious Movements-Types and Dynamics, 542.
} 
Ghana's past and current economic as well as spiritual woes. ${ }^{39}$ The singular act of the ancestors, he claims, has brought both spiritual and material challenges to the nation and this can only be surmounted when the nation wholeheartedly accepts as well as believe in the Asomdwee Ntonton Nkabom Som. Until then, the nation will continue in its present predicaments both spiritually and materially. ${ }^{40}$

Although Nyame Somafo Yaw does not promise his adherents a return to a golden age of African culture or the coming of a future millennium as posited by Fernandez, he promises his adherents a life devoid of any form of physical or material suffering as well as salvation. He opines that any person who worships God faithfully is not supposed to lack any material thing in life or be taken ill. ${ }^{41}$ In this regard, during conferences, he prays for the adherents for their material wellbeing.

\section{THE THEOLOGY OF THE FAITH}

Raman Varadaraja observes that religion is a cultural framework that is based on prescribed beliefs and practices to which significant number of people subscribe. ${ }^{42}$ It is equally true that religion drives on the wheels of culture since religion is revealed within a cultural context. Thus, the Asomdwee Ntonton Nkabom Som was revealed within the Fante culture. In this regard, the message being preached by Nyame Somafo Yaw is clothed with the Fante culture.

As Emmanuel K. Larbi rightly observed, every culture has within its religious system certain practices directed towards the achievement of a highest goal. ${ }^{43}$ The Asomdwee Ntonton Nkabom Som is guided by certain beliefs and practices towards the achievement of its highest goal. According to the founder, Nyame Somafo Yaw, in order for anyone to have total freedom in life, one needs to live according to the prescribed beliefs and practices of the faith as revealed to him by RABBI. Any member, who acts contrary to any of the beliefs and practices of the faith, largely, is bond to face consequences. ${ }^{44}$ Similarly, non-adherents of the faith would not attain their highest goal in life as long as they refused to accept the Asomdwee Ntonton Nkabom Som. This implies that the faith provides practical answers meant to guide the life of adherents. Additionally, the central function of the faith, through its prescribed beliefs and practices, is to provide solutions or answers to the teaming life challenges facing the adherents. ${ }^{45}$ Hence, living by the tenets of the faith leads to the spiritual growth of an adherent. The question then, is what is the prescribed theology of the faith?

\section{The True God}

The faith, which is monotheistic, has as its core belief in the one most High God called RABBI, who is the greatest of all Gods and the Creator of the universe. The faith admits the existence of pantheons of Gods in the universe, yet it views RABBI as the only Uncreated Creator of the Universe. The faith's monotheistic nature is reflected in their belief in the oneness of RABBI and that RABBI is the only entity truly worthy of worship. ${ }^{46}$ Adherents are supposed to worship or seek for assistance from no other God except from RABBI. The faith, like Islam rejects the concept of the trinity, which is in sharp contrast to what's known in the circles of the Christian faith, that is, most Christian denominations.

\section{The Promised Messiah}

The faith believes that Nyame Somafo Yaw is the Promised Messiah for the end time sent by RABBI to redeem Ghana from all forms of evil spirits, convert the nation into a Godly nation, lead, and guide Africa and the rest of the world to the true worship of RABBI. In addition, adherents are to believe in the messianic deeds of Nyame Somafo Yaw, which goes to vindicate him as indeed a Messiah sent from God. The movement practices Bay'ah, which literally refers "to sell" something ${ }^{47}$ In this regard, it is interpreted as a person offering himself/herself to the will of his/her religious leader. This is an act of declaring an oath of allegiance to a particular leader, which in most cases, a religious leader. In other words, it is the standard procedure of pledging allegiance to a religious leader. Additionally, the act allows an adherent of a faith to demonstrate his/her complete acceptance of the Divine appointment and authority of his/her religious founder/leader. ${ }^{48}$ In this concern, the Bay'ah allows the adherents of the Asomdwee Ntonton Nkabom Som to testify that Nyame Somafo Yaw is a representative (Messiah) of RABBI on earth. Ba'yah is an important feature in the Asomdwee Ntonton Nkabom Som. In fact, just like Islam, it is the standard procedure for formally joining the Asomdwee Ntonton Nkabom Som fraternity. The recitation of the $B a^{\prime} y a h$ is led by the spiritual leader of the group. Here, adherents declare belief in the oneness of RABBI and accept Nyame Somafo Yaw as RABBI's Messiah and this is similar to the Kalimatu Shahadah in Islam. The second part of the declaration indicates the means by which RABBI

\footnotetext{
Shaibu, Nyame Somafo Yaw: His calling, mission and Messiahship, 19

40 Nyame Somafo Yaw (Founder and Leader, Asomdwee Ntonton Nkabom Som) in discussion with the author, October 15, 2019.

41 This does not mean he is against any form of Western medication.

42 Raman, Varadaraja, “On the founders of religions". (2019) Accessed January 12, 019,https://metanexus.net/founder-religions/

Kingsley, E. Larbi, Pentecostalism: The eddies of Ghanaian Christianity. (Accra: CPCS, 2001).6

4 Nyame Somafo Yaw (Founder and Leader, Asomdwee Ntonton Nkabom Som) in discussion with the author, October 15, 2019.

John, Hick, An interpretation of religion. Human response to the transcendent. (London: Macmillan, 1989).

6 Shaibu, Nyame Somafo Yaw: His calling, Mission and Messiahship, 2.

Walker, Adam, Pledge of Allegiance (Bay’ah) (n.d.) https://www.alislam.org/articles/pledge-of-allegiance (Accessed January 15, 2020)

Ibid
} 
gives guidance to humanity. The declaration reminds adherents that they accept Nyame Somafo Yaw as the Promised Messiah of RABBI. Before a person becomes a member, one of the requirements is that such a person must recite the declaration of faith a number of times in the presence of witnesses with total sincerity as well as full understanding of what it means. The founder currently administers the oath of allegiance and this is administered in Fante. The declaration can be personal or in the presence of other people or congregational as depicted fig 2 below.

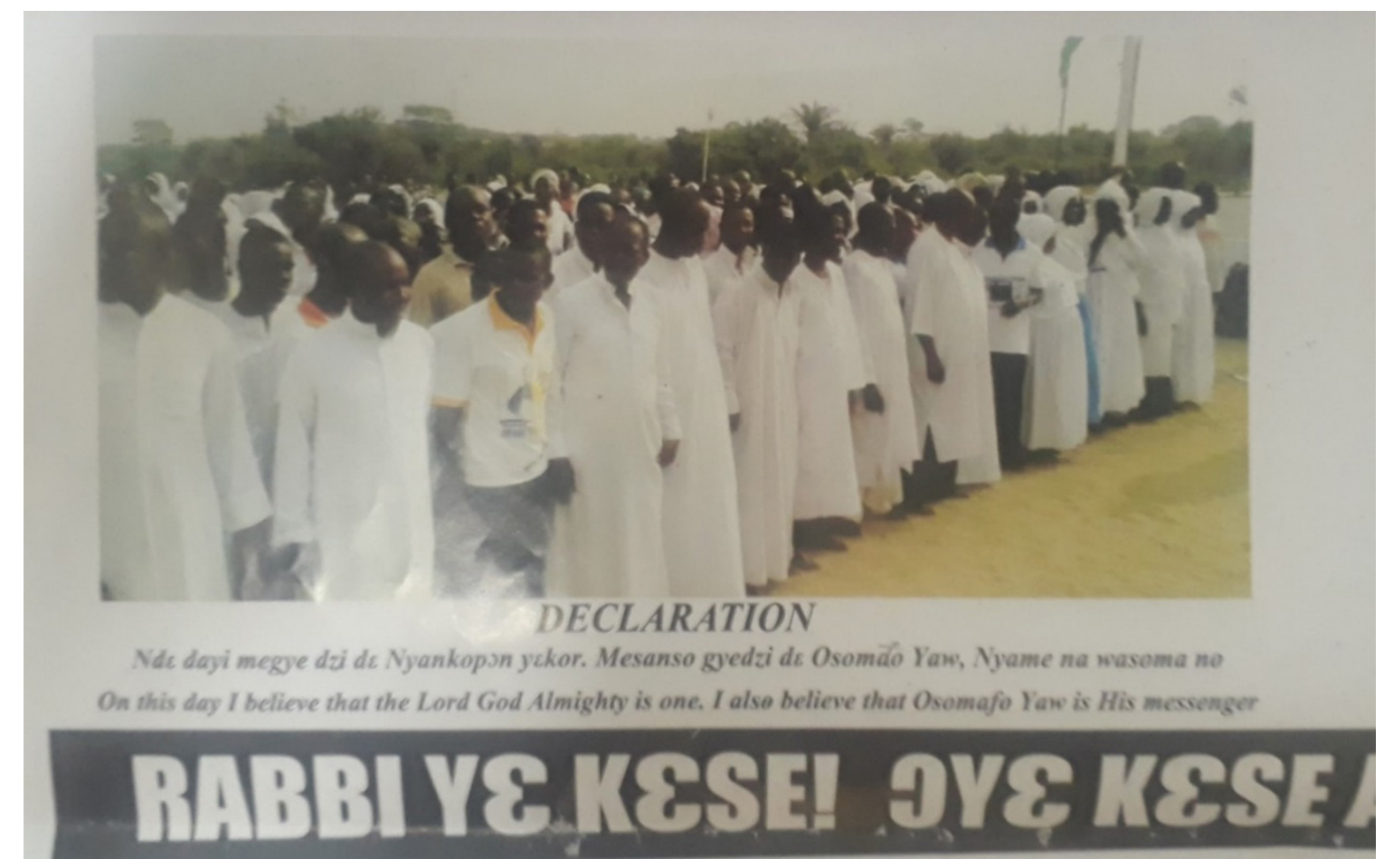

Fig 2 indicating a congregation of the movements reciting the Ba'yah during one of their worship days

The focus is the internal acceptance of truth and making a commitment to lead one's life in accordance with the will of RABBI. Any adherent who cannot recite this wholeheartedly is not recognised as a full fledge member. Some implications can be deduced from the declaration and these are;

i. RABBI is the only true God, and Nyame Somafo Yaw is the Promised Messiah of the world.

ii. The adherents accept this as true.

iii. Adherents are expected to obey all the commandments of the faith in their life. The non-adherence of any of the tenets of the faith has consequences.

iv. Adherents are to surrender themselves to the will of Nyame Somafo Yaw.

The declaration and its implications are similar, if not the same, as what pertains in Islam. Could it be that the founder and leader of the movement was influenced by his Islamic background?

\section{The Prophets and Messiahs}

Adherents are entreated to believe in all the past and future prophets as well as Messiahs of RABBI. The past prophets start from Adam to Muhammed, the founder of Islam and the Messiahs from Enoch to Nyame Somafo Yaw. In a telephone interview with Nyame Somafo Yaw, he opined that RABBI has sent about five hundred and thirteen prophets in the world in two categories. ${ }^{49}$ The first had to do with the sending of two hundred out of this figure before Noah's flood and the second category had to do with the remaining figures, which were sent after the flood. ${ }^{50}$ The breakdown of the second category was, three hundred prophets were from Israel, seven from Media, four from Syria and two from Arabia. ${ }^{51}$ Regarding the Messiahs, he posited that RABBI has sent, since the time of creation to date, thirty Messiahs in the world. Out of this number, Enoch was first and he came before Noah's flood, and the remaining twenty-nine were sent after Noah's flood. Out of the twenty-nine, twenty-eight were from Israel and one from Ghana. ${ }^{52}$ Regarding

\footnotetext{
49 Nyame Somafo Yaw (Founder and Leader, Asomdwee Ntonton Nkabom Som) in discussion with the author, April 18, 2020.

50 The first category is from Adam to Noah

51 Media is an ancient country of northwestern Iran generally corresponding to the modern regions of Azerbaijan, Kurdistan, and parts of Kermanshah.

52 That is referring to Nyame Somafo Yaw.
} 
the future messengers of RABBI, the faith believes in the coming of the last Messiah that will be sent by RABBI after Nyame Somafo Yaw and who will be a Syrian. He is the Elijah who will witness the end of this world. RABBI only knows the date for the coming of this Messiah. ${ }^{53}$ The coming of the last Messiah implies that RABBI has designed to send thirty-one Messiahs to this world, and in exception of the last one, the others came to liberate humanity from satanic bondage and redirect RABBI's children to His true worship.

\section{Sacred Books}

The faith believes in all the sacred books revealed by RABBI through the angels to His respective Messengers. In this regard, the faith believes in the Old Testament that was given to Moses or Musa, the New Testament to Yeshua (Jesus) and Muhammed (S.A.W.) the Quran. Aside these revealed sacred books, the faith believes in what it calls the Mother Book (Tum Nwoma ${ }^{54}$ ). Nyame Somafo Yaw posits that the Mother Book, which is currently being revealed in a piecemeal fashion by RABBI, when completed will be more powerful or potent than any given scripture in the world. ${ }^{55}$

Since the Supreme Being reveals Himself to humanity within a cultural context, culture is thus the "vehicle" which transports the gospel of any given faith. In this concern, the Akan culture and specifically, Fante, is the vehicle for the transmission of the gospel of the Asomdwee Ntonton Nkabom Som. According to the founder, the duration for the revelation and subsequent completion of the Mother Book depends on RABBI. Interestingly, the founder opines that the recitation of any revealed portion of the Tum Nwoma in any other dialect apart from the Fante, will render such a recitation invalid. ${ }^{56}$ The rationale for his claim is to guide against the translation of the Tum Nwoma into different dialects, which eventually would result in some form of distortion of the original message of RABBI as we have in some religions today. Currently, aside what has been revealed, the faith uses the Torah, Bible, the Book of Barnabas and the Quran.

\section{Baptism of the Holy Spirit and Fire}

The adherents of the Asomdwee Ntonton Nkabom Som believe in the Baptism of the Holy Spirit and with Fire as stated in the Bible (cf. Matt. 3: 11). The faith's stand regarding this issue is based on the claim of John the Baptist who said he baptises with water but the one that comes after him baptises with Holy Spirit and fire. According to the founder, John the Baptist was actually referring to him and not Jesus. He further claimed that Jesus Christ never baptised any person since that was not what he was sent to do. Nevertheless, in Acts 1:5, Jesus Christ charged the disciples to stay in Jerusalem in order to receive God's promise, which was to be fulfilled not many days hence. In this concern, one wonders how John the Baptist's claim is related to Nyame Somafo Yaw.

Concerning baptism of new converts, this is usually done by the founder who places his hand on the head of a convert and prays for such a person to receive or be imparted with the Holy Spirit and spiritual fire as depicted in the illustration fig 3 below.

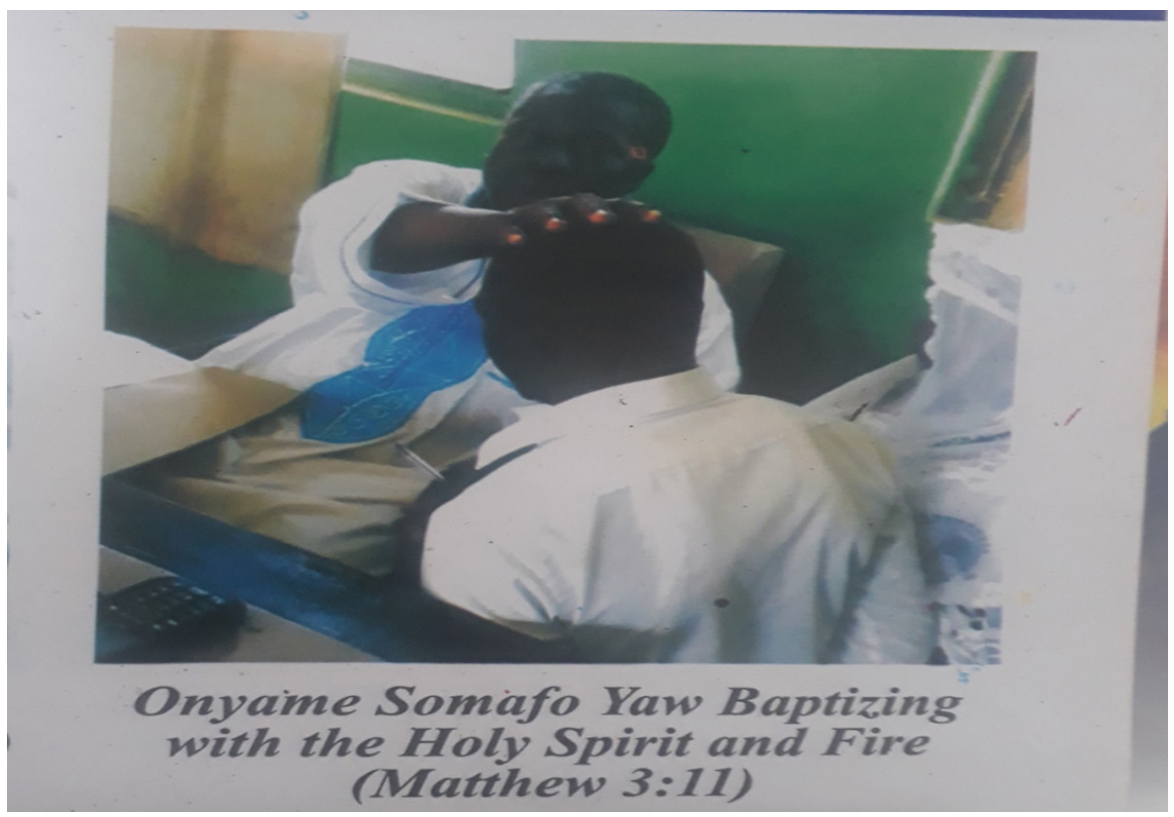

Fig 3: illustrating Nyame Somafo Yaw baptizing a convert

\footnotetext{
53 Nyame Somafo Yaw (Founder and Leader, Asomdwee Ntonton Nkabom Som) in discussion with the author, April 18, 2020.

54 This literally means Book of Power and the revelation started in 2014.

55 Nyame Somafo Yaw (Founder and Leader, Asomdwee Ntonton Nkabom Som) in discussion with the author, October 15, 2019.

56 Ibid
} 
The impartation aids the convert to build an intimate relationship as well as ensure the assistance of RABBI in the life of the believer. In other words, it "draws one closer to RABBI for a personal religious experience". ${ }^{57}$

\section{The Third Temple of God}

Nyame Somafo Yaw, under the guidance of RABBI has built a temple at the headquarters at Ankamu, few meters from the Apam Junction in the Gomoa West District of the Central Region of Ghana. His followers are obliged to believe in the divinity of the Commission of the building of the Temple, which was done by Nyame Somafo Yaw. ${ }^{58}$ In addition, adherents are to believe in the Kaba in Mecca, Saudi Arabia and the temple built by King Solomon in Israel.

The temple stands at nine feet square and according to the founder and leader, RABBI informed him that the temples built by the prophet of Islam and that of King Solomon are seven feet square and this implies that his temple is bigger than that of Mecca and that of Solomon's. Aside it being bigger, the glory of his temple, the founder and leader remarked, is greater than the two mentioned above. This he made reference to Haggai 2:9 that reads, "the glory of this latter house shall be greater than the former, saith the LORD of hosts: and in this place will I give peace, saith the LORD of hosts" (KJV).

Beside the glory and magnificence mentioned above regarding his temple, adherents having life challenges or those who wish to glorify RABBI can do so by undertaking a pilgrimage to the location of the temple and going around the temple nine times reciting RABBI YJ KJSE! CYJ KJSE AMPA $!^{59}$ They are mandated to undertake similar pilgrimage during minor or major conferences of the faith, which takes place on the second Thursday of August and December each year. Pilgrimage can be done at any day and time of the day. Nevertheless, during conferences, it is undertaken at 9:00pm. According to Nyame Somafo Yaw, the faith would be well established in Ghana by 2024 after which the pilgrimage would be institutionalised once annually. When it becomes institutionalised, then it would be undertaken during the major conference, which is held in December each year. The institutionalisation of the pilgrimage would mean that daytime pilgrimages would stop.

Before the institutionalisation, it is important to note that there are certain conditions one ought to fulfil before embarking on a pilgrimage. One has to know or be certain of the rationale for the pilgrimage and walk bare footed whiles going around the temple. Additionally, Nyame Somafo Yaw can only permit a woman in her menstrual cycle depending upon how threatened her life situation is. ${ }^{60}$

Meanwhile, before the pilgrimage is institutionalised, RABBI has days set aside for specific blessings whenever a believer goes around the temple and these days are;

Monday is meant for accumulation of power to undertake a journey, a business project and/or to realise one's aspirations in life. For instance, people seeking for political position can go around the temple and with faith they will be victorious. Tuesday, any adherent who seeks personal growth or life development should undertake the pilgrimage on Tuesday. Wednesday is meant for victory over one's enemy in every life situation. Thursday is set aside by God to forgive the sins and iniquities of humankind. Hence, any believer who seeks forgiveness should undertake the pilgrimage on this day. Friday is meant for healing. Thus, people with health challenges go around the temple the required number of times and with faith have their healing. Saturday is for childless couples. Couples with barrenness or infertility challenges are also mandated to undertake the pilgrimage in faith and earnest expectation and surely, RABBI will meet their needs. Sunday has been designated for progress/victory in every sphere of life. Any adherent who seeks personal or life related progress or life development should undertake the pilgrimage on Sunday.

Aside the temple, on 24 $4^{\text {th }}$ March, 2014, around 2:00 am, RABBI revealed a heavenly rod to the leader and instructed the latter to physically fashion one, this has been done. The rod, according to the founder, is similar to what RABBI gave to Moses. The rod is currently locked in the temple and will only be used under the instruction and guidance of RABBI.

\section{God's Ordained Third Nation}

It is the belief of the adherents of the faith that the RABBI ordained three 'nations', which were very dear and unique to Him and in these nations, He established His Religion. The "nations" were and still are Israel, Mecca and Assyriawhich refers to the Akans of Ghana. ${ }^{61}$

\section{The Judgement Day}

The movement believes in the last Day of Judgment in which all humanity, both living and dead will account for their

\footnotetext{
57 Nyame Somafo Yaw (Founder and Leader, Asomdwee Ntonton Nkabom Som) in discussion with the author, October 15, 2019.

58 He refers to his temple as the Third Temple of God; majority of the Israelites expected Jesus Christ to have built the third Temple. Nevertheless, since it was not part of Jesus' mission, he did not do so.

59 This is the Fante dialect which literally means RABBI is Great and indeed He is Great! This is a replica of what takes place during Hajj.

60 Nyame Somafo Yaw (Founder and Leader, Asomdwee Ntonton Nkabom Som) in discussion with the author, October 15, 2019.

61 Nyame Somafo Yaw (Founder and Leader, Asomdwee Ntonton Nkabom Som) in discussion with the author, October 15, 2019.
} 
stewardship. Those who led lifestyles pleasing to RABBI will attain Heaven and the opposite would go to Hell. ${ }^{62}$

\section{Healing and/ or Deliverance}

The faith under study practices healing and deliverance from all forms of sicknesses and satanic bondages. In line with this, the faith has a designated place, a consulting room of a sort meant for listening and addressing of the numerous challenges facing adherents. Sometimes, aside the free counselling given to adherents, individual healing and deliverance are also performed in the spiritual consulting room. Aside this, healing and deliverance takes place during their routine worship services and usually after sermon of the day has been preached. Here, the faith has two methods it uses and these are the direct and medium approaches to deliverance. The direct is similar to what happens in churches involved in deliverance and/or healing today. This is where the evil spirit tormenting a person reveals itself or speaks through the person it possesses. The "medium" approach is where an evil spirit tormenting a person, in turn, possesses a third person and speaks through that medium. Here, the faith has four female mediums illustrated fig 4 below.

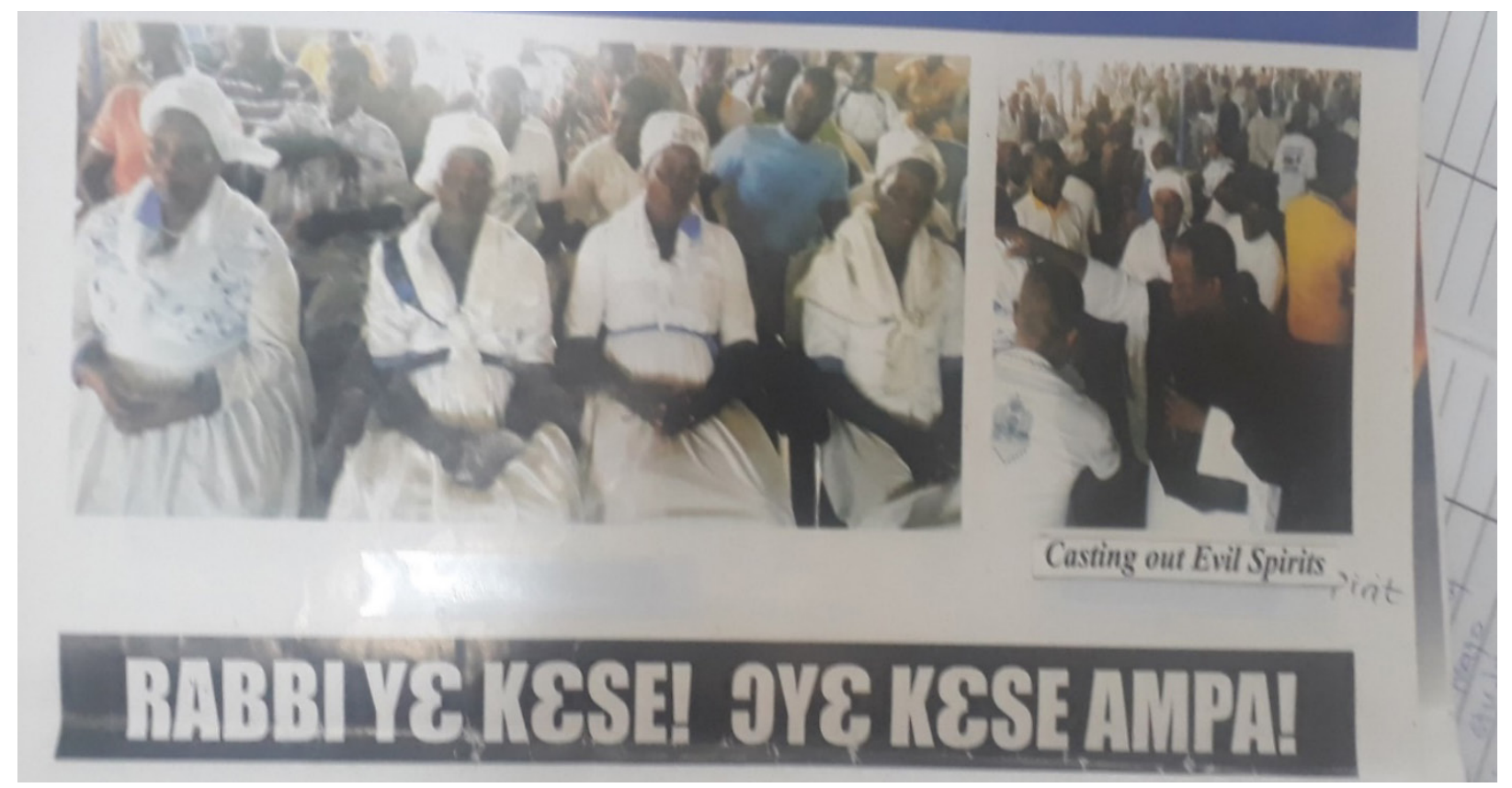

Fig 4: indicating the four mediums (the front row regarding the photograph on the left. The photograph on the rightillustrate Nyame Somafo Yaw delivering a demon-possessed member. The second is typical of what pertains in most churches regarding exorcism.

Interestingly, when a medium is possessed, it moves to where the deliverance is taking place and communicates with Nyame Somafo Yaw. The possessed medium becomes more powerful and sometimes ruthless and such a medium has to be calmed by three or four strong men. Before exorcising the evil spirit, the founder finds out the motive(s) behind the evil spirit's act, after which he commands the spirit to leave and return no more. In the course of the deliverance, the founder recites or sings the following;

Fante
Ogya! Amen!
Wura ne mu! Amen!
Sumsum fi! Amen!
Fir ne mu! Amen!
Fir ne mu fi! Amen!
Ma ondze ne ho
Ogya! Amen!

Wura ne mu! Amen!

Sumsum fi! Amen!

Fir ne mu! Amen!

Ma ondze ne ho

Ogya! Amen!

\author{
English \\ Fire $^{63}$ ! Amen! \\ Get into him/her! Fill him/her! \\ Bad/evil spirit! Amen! \\ Get out of him/her! Amen! \\ Get out of him! Amen! \\ For him/her to be freel \\ Fire! Amen!
}

It is worth noting that there is no specific number of times each line is recited. The number or frequency usually depends on the prompting of the Spirit of RABBI. It is equally significant to note that for each line that is recited, the

63 This refers to God's spiritual fire.
} 
congregation responses, Amen! Additionally, RABBI gave this recitation to the Messiah two years after he started his healing ministry.

Sometimes, members who are recalcitrant to the tenets of the faith face consequences and after genuine repentance need to be delivered. A female member testified during one of their worship services how she intentionally decided to drink alcohol, which is in contrast to the teachings of the faith, and went through many ordeals because of her action. ${ }^{64}$ She posits that she had to confess and ask for forgiveness on phone to Nyame Somafo Yaw, and the latter prayed and delivered her from her predicament.

\section{CONCLUSION}

It has been observed that NRM is a worldwide phenomenon, which is complex and diverse in nature and this in a way, has partially contributed to the lack of a consensus regarding a precise definition of the concept. It is no doubt that globalisation has created a fertile ground for the proliferation of this phenomenon especially in the twentieth century. Since the proliferation, scholars have used similar and different indices and criteria to interpret, analyse and construct classificatory models of the concept. The classifications have been based on structures, doctrines and liturgies. With the aid of existing taxonomies, the Asomdwee Ntonton Nkabom Som was classified as a Hebrais messianic movement. As a Hebrais messianic movement, members are obliged to strictly observe its theology in order for them to attain their highest goal in life. The non-adherence of its theology has repercussions on the life of members.

It is worth noting that Nyame Somafo Yaw made allusions regarding some biblical references that have no correlation to either his personality or activity related to his mission. He claimed that such verses have relations with his activities as a Messiah hence, the reference. Additionally, aside it being monotheistic, the faith has its unique and distinct theology, which to some extent, resembles or is similar to that of Christianity and Islam. What is more, members are mandated to believe in the Bible, Quran as well as the past, present and future messengers of RABBI including those found both in the Bible and Quran. This to some extent makes the Asomdwee Ntonton Nkabom Som to be seen outwardly as an amalgamation of Christianity and Islam. That is, culturally, a syncretism of Christianity and Islam. To this extent, there is the need for further research to unearth the theology and cultural dimension of the faith.

\section{BIBLIOGRAPHY}

Adam, Walker, Pledge of Allegiance (Bay'ah) (n.d.) Accessed January 15, 2020 https://www.alislam.org/articles/pledge-of-allegiance

Barker, V. Eileen. New religious movements: A practical introduction. London: HMSO, 1989.

Barrett, B. David. Schism and Renewal in Africa: An analysis of six thousand contemporary religious movements. London: Oxford University Press, 1968.

Bromley, G. David, Perspective: "Whither New Religions Studies?" Nova Religious: The Journal of Alternative and Emergent Religions, 8 (1) (2004):83-97. Accessed April 5, 2019, https://doi.org/10.1525/nr.2004.8.1.73.

Cooper, T. Michael, Druids Globalization and Constructing a Postmodern Religious Identity. Centre for the Study of New Religions. The 2007 International Conference 7-9, Bordeaux, France 2007.

Fernandez, W. James, "African Religious Movements-Types and Dynamics”. Journal of Modern African Studies.

Vol. 2. No 4. (Dec. 1964):531-549. Accessed April 5, 2019, https//www.jstor.org/stable/159275

Giles, W. Glenn. Messianic Movements of the First century. Trinity Theological Seminary. Newburgh, Indiana, 2002.

Hick, John. An Interpretation of Religion. Human response to the transcendent. London: Macmillan, 1989.

Ibrahim, Murtala, "The Rise and Proliferation of New Religious Movements in Nigeria". International Journal of Humanities and Social Science, Vol. 3 No. 15 (2013):181-190, Accessed January 21, 2020

http://www.ijhssnet.com/journals/Vol_3_No_15_August_2013/21.pdf

Larbi, E. Kingsley. Pentecostalism: The Eddies of Ghanaian Christianity. Accra: CPCS, 2001

Lucass, Shirley, The Concept of the Messiah in the Scriptures of Judaism and Christianity. New York: T \& T Clark 2011. Accessed July 13, 2019. http://onlinelibrary.wiley.com/doi/abs/10.1111/j.1748-0922.2012.01601_22.x

Macquarrie, John. Principles of Christian Theology. London: SCM Press, 1966.

McGrath, E. Alister. Christian Theology: An introduction (Second Edition). Oxford: Blackwell Publishers Ltd. 1997. Melton, J. Gordon, “Toward a Definition of "New Religion". Nova Religio: The Journal of Alternative and Emergent Religions. 8 (1), (2004): 73-87. Accessed April 5, 2019, https://doi.org/10.1525/nr.2004.8.1.73

Nmah, E. Patrick, "What is New in 'New' religious Movements in Africa? An analytical approach". IGWEBUIKE: An African Journal of Arts and Humanities. Vol.3 No. 2(2488-9210) (2017): 46-62

Randall, Price, The concept of the Messiah in the Old Testament - World of the Bible ... Accessed July 12, 2019.

\footnotetext{
${ }_{64}$ Name withheld for personal reason.
} 
http://worldofthebible.com/wp-content/uploads/2017/03/The-Concept-of-the-Messiah-in pdf.

Saliba, A. John, "Understanding New religious movements". Nova Religio: The Journal of Alternative and Emergent Religions, 8 (3), (1997):122-123. Accessed April 5, 2019. https: doi.org/10.1525/nr.2005.8.3.122

Shaibu, A. Iddrissu, "Nyame Somafo Yaw: His calling, mission and Messiahship". Oguaa Journal of Religion and Human Values. (2019) Vol. 5: Issue 1:1-17.

Turner, W. Harald. History of an African Independent Church. Oxford: Clarendon Press, 1967. Profile through preaching. London: Edinburg House, 1984.

"Africa." The Study of Religion: Traditional and New Religion, edited by Stewart Sutherland and Peter B. Clarke, London: Edinburg House, 1991. 187-194.

“Religious movements in primal societies". New Vista Missionary and Ecumenical, 9 (3),(1981).48-49.

Varadaraja, Raman. "On the founders of religions". (2019) Accessed January 12, 019,https://metanexus.net/founderreligions/

Weaver, Jo Mary. Introduction to Christianity. California: Wadsworth Publ. Company, 1984.

Wilson R. Bryan. Magic and the Millennium: A Sociological Study of Religious Movements of Protest Among Tribal and Third World Peoples. London: Harper \& Row, 1973.

Wilson, Bryan, and Cresswell, Jamie (editors), New Religious Movements: Challenge and Response. New York: Routledge, 1999. 